\title{
Kinetic-Mechanistic Studies of $P$. cepacia Lipase Catalyzed Corona Charge Selective Micelle Degradation
}

Xiaobo Zhu, ${ }^{a}$ Michael Fryd, ${ }^{a}$ Carlos Barrero, ${ }^{b}$ Salim Merali, ${ }^{b}$ Chiara Fecchio, ${ }^{b}$ Ann M. Valentine, ${ }^{a}$ and Bradford B. Wayland ${ }^{a, *}$

a) Department of Chemistry, Temple University, Philadelphia, PA 19122, United States

b) Department of Pharmaceutical Sciences, School of Pharmacy, Temple University, Philadelphia, PA 19140, United States 
Abstract: The polyester cores of micelles that self-assemble from poly(caprolactone)poly(ethylene oxide) block copolymers (HO-PCL-b-PEO-X) are substrates for P. cepacia lipasecatalyzed hydrolytic degradation. The charge on the micelle corona can be modified by varying the PEO end group $(\mathrm{X})$ with neutral $\left(-\mathrm{CH}_{2} \mathrm{CH}=\mathrm{CH}_{2},-\mathrm{OMe}\right)$, positively charged $\left(-\mathrm{NH}_{3}{ }^{+}\right)$, or negatively charged $\left(-\mathrm{CO}_{2}^{-},-\mathrm{SO}_{3}^{-}\right)$groups. The latter set of substrates has the added benefit that the corona charge can be changed by varying the $\mathrm{pH}$. P. cepacia lipase has isoforms that manifest highly selective catalytic degradation of micelles depending on the corona charge. One isoform or group of isoforms (L(I)) selectively hydrolyze micelles with neutral or negatively charged coronas, whereas a second isoform or group of isoforms (L(II)) selectively hydrolyze micelles with neutral or positively charged coronas. The L(I) isoform was selectively inhibited, exposing the activity of the L(II) form. The occurrence of $P$. cepacia isoforms that was initially revealed by kinetic studies has been confirmed by two-dimensional gel electrophoresis with isoelectric focusing. Micelle surface charge could be employed as a strategy in the design of micelles for control of the transport and release of therapeutic substances. 
Key Words: P. cepacia Lipase Enzyme, Block Copolymer Micelles, Polyester Core hydrolysis, Corona Charge Dependent Catalysis, Micelle Degradation, Enzyme Kinetics and Mechanism

\section{Introduction}

Catalytic hydrolysis of lipid ester substrates assembled in bilayers, vesicles and micelles is an exclusive capability of lipase enzymes [1-8]. Activation of catalytic substrate hydrolysis through binding of an assembly of ester substrates with the lipase enzyme at the hydrophobicwater interface is a characteristic of "interfacial activation" and a classic feature that distinguishes lipase and esterase behavior [9-12]. Lipase catalyzed ester hydrolysis is involved in diverse biological processes ranging from metabolism of triglycerides to inflammation [13] and cell signaling [14]. Amphiphilic block copolymer micelles with hydrophilic corona and hydrophobic core have diverse biomedical applications [15-18] and in particular provide a broad platform for development of drug and gene delivery vehicles that function through their capability for loading, transport and release of lipophilic substances incorporated in the hydrophobic core [19-26]. Several lipase enzymes including those from C. rugosa, $P$. fluorescens and P. cepacia catalyze ester hydrolysis and degradation of micelles from HO-PCLb-PEO-OMe diblock copolymers [27-33], and lipase catalyzed micelle degradation provides a strategy for targeted drug release. The lipase catalyzed process proceeds through interfacial activation, which occurs several orders of magnitude faster than either acid or base catalyzed ester hydrolysis processes for $\mathrm{HO}-\mathrm{PCL}_{\mathrm{n}}-b-\mathrm{PEO}_{\mathrm{m}} \mathrm{X}$ micelles $[30,34]$. The products from the interfacial activation step include water soluble $\mathrm{HO}-\mathrm{PCL}_{\mathrm{n}}-b-\mathrm{PEO}_{\mathrm{m}}-\mathrm{X}(\mathrm{n} \leq 6)$ fragments and a set of small $\mathrm{HO}-\mathrm{PCL}_{\mathrm{n}}-\mathrm{CO}_{2} \mathrm{H}(\mathrm{n} \leq 6)$ oligomers, which have ester groups that compete for binding in the catalytic center and inhibit the lipase enzyme activity. P. cepacia lipase also catalyzes a 
relatively slow esterase hydrolysis of the water soluble polyesters which proceeds over a period of days to the complete formation of caproic acid $\left(\mathrm{HO}\left(\mathrm{CH}_{2}\right)_{5} \mathrm{CO}_{2} \mathrm{H}\right)$ and $\mathrm{HO}-\mathrm{PEO}_{\mathrm{m}}-\mathrm{OH}(\mathrm{Scheme}$ 1). The final products lack ester units and thus are not P. cepacia lipase inhibitors which is evidenced by full restoration of $P$. cepacia lipase enzyme activity [30].

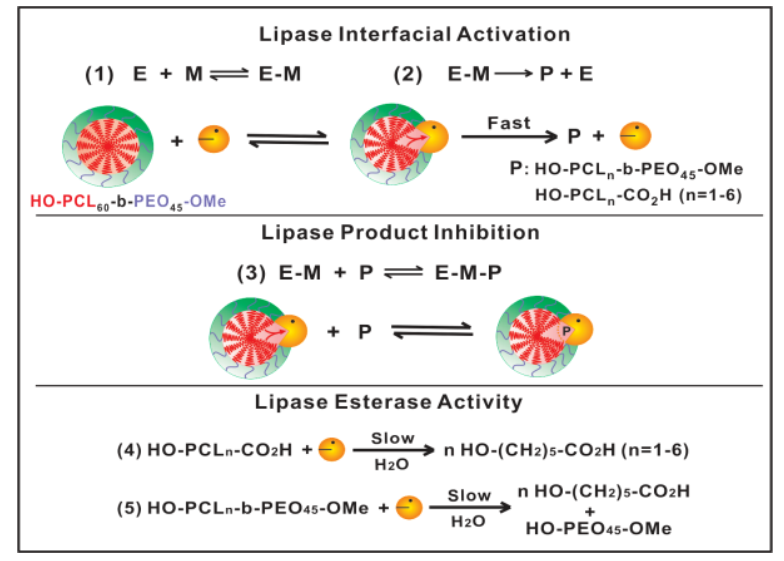

Scheme 1. Schematic $\mathrm{HO}-\mathrm{PCL}_{60}-\mathrm{b}-\mathrm{PEO}_{45}-\mathrm{OMe}$ micelle-lipase catalyzed micelle degradation and polyester hydrolysis. E= Enzyme; $\mathrm{M}=$ Micelle; $\mathrm{P}=$ Enzyme Inhibitor

This article reports on the dramatic effects observed for $P$. cepacia lipase catalyzed micelle degradations that result from placing groups with different charges on the terminus of the micelle polyethyleneglycol corona. Kinetic studies suggest the presence of several isoforms of $P$. cepacia lipases through observing opposite corona charge selective micelle degradation, which is confirmed by observation of a series of $P$. cepacia lipase isoforms by two-dimensional gel electrophoresis. 


\section{Materials and Methods}

Full experimental details are given in the Supplemental Materials. Briefly, block copolymers of $\operatorname{poly}(\varepsilon$-caprolactone) with poly(ethylene oxide) (HO-PCL $-b$-PEOm-X) are prototypical amphiphilic block copolymers that self-assemble into core-shell micelles in water where the hydrolytically non-degradable hydrophilic PEO segment forms the exterior corona and the core contains the hydrolytically degradable polyester hydrophobic PCL block [17, 35-41]. Thiol-ene "click" chemistry [42-44] of an allyl-terminated block copolymer (HO-PCL $-b-\mathrm{PEO}_{\mathrm{m}}$ $\left.\mathrm{CH}_{2} \mathrm{CH}=\mathrm{CH}_{2}\right)$ was used to introduce end groups on the PEO segment that are anionic $\left(-\mathrm{CO}_{2}{ }^{-}\right.$, $\left.-\mathrm{SO}_{3}{ }^{-}\right)$and a Michael addition $[45,46]$ was used to place a positively charged group $\left(-\mathrm{NH}_{3}{ }^{+}\right)$on the micelle corona.

The series of diblock copolymers $\mathrm{HO}-\mathrm{PCL}_{51}-b-\mathrm{PEO}_{32}-\mathrm{CH}_{2} \mathrm{CH}=\mathrm{CH}_{2}$, $\quad\left[\mathrm{HO}-\mathrm{PCL}_{51}-b\right.$ $\left.\mathrm{PEO}_{32}-\mathrm{RCO}_{2}\right]^{-} \mathrm{Na}^{+},\left[\mathrm{HO}-\mathrm{PCL}_{51}-b-\mathrm{PEO}_{32}-\mathrm{RSO}_{3}\right]^{-} \mathrm{Na}^{+}$and $\left[\mathrm{HO}-\mathrm{PCL} 44-b-\mathrm{PEO}_{32}-\mathrm{RNH}_{3}\right]^{+} \mathrm{Cl}^{-}(\mathrm{R}=$ $\left.\left(\mathrm{CH}_{2}\right)_{3} \mathrm{~S}\left(\mathrm{CH}_{2}\right)_{2-}\right)$ were used to produce a set of micelles with neutral, negatively and positively charged groups at the terminus of the corona. Diblock copolymer micelles for these polymers were formed by the nano-precipitation method that was previously used to form micelles of MeO-PEO- $b$ - -OH diblock copolymers [47-50]. Results from dynamic light scattering (DLS) studies for these micelle solutions are given in Fig. S1. All of the micelle solutions display unimodal dynamic light scattering (DLS) traces and narrow size distributions with average diameters of $30-40 \mathrm{~nm}$ depending on the micelle. TEM images for the allyl and $-\mathrm{CO}_{2}{ }^{-}$capped micelles indicate the exclusive formation of spherical micelles (Fig. S1). ${ }^{1} \mathrm{H}$ NMR spectra for aqueous dispersions of the block copolymer micelles of $\mathrm{HO}-\mathrm{PCL} 51-b-\mathrm{PEO}_{32}-\mathrm{CH}_{2} \mathrm{CH}=\mathrm{CH}_{2}$, $[\mathrm{HO}-$ $\left.\mathrm{PCL}_{51}-b-\mathrm{PEO}_{32}-\mathrm{RCO}_{2}\right]^{-} \mathrm{Na}^{+}, \quad\left[\mathrm{HO}-\mathrm{PCL}_{51}-b-\mathrm{PEO}_{32}-\mathrm{RSO}_{3}\right]^{-} \mathrm{Na}^{+} \quad$ and $\quad\left[\mathrm{HO}-\mathrm{PCL} 44-b-\mathrm{PEO}_{32}-\right.$ 
$\left.\mathrm{RNH}_{3}\right]^{+} \mathrm{Cl}^{-}\left(\mathrm{R}=\left(\mathrm{CH}_{2}\right)_{3} \mathrm{~S}\left(\mathrm{CH}_{2}\right)_{2}-\right)$ are broadened compared to water-soluble molecules, but each of the ${ }^{1} \mathrm{H}$ resonances can be observed and assigned (Fig. S2) [30]. The capability to observe the ${ }^{1} \mathrm{H}$ NMR of these micelle dispersions provides a direct method to evaluate the relative micelle concentrations for kinetic and mechanistic studies of $P$. cepacia lipase catalyzed micelle degradations. The commercial $P$. cepacia lipase was resolved into isoforms by using two dimensional gel electrophoresis.

\section{Results}

3.1. Kinetics of P. cepacia lipase catalyzed degradation of block copolymer micelles with neutral and charged groups on the corona

Addition of $P$. cepacia lipase to dispersions of $\left[\mathrm{HO}-\mathrm{PCL}_{51}-\mathrm{b}-\mathrm{PEO}_{32}-\mathrm{RCO}_{2}\right]^{-} \mathrm{Na}^{+}$micelles in aqueous PBS buffer $\left(\mathrm{pH} 7.4, \mathrm{~T}=37^{\circ} \mathrm{C}\right.$ ) results in hydrolytic degradation of micelles, which are conveniently followed by ${ }^{1} \mathrm{H}$ NMR (Fig. 1) [30]. 


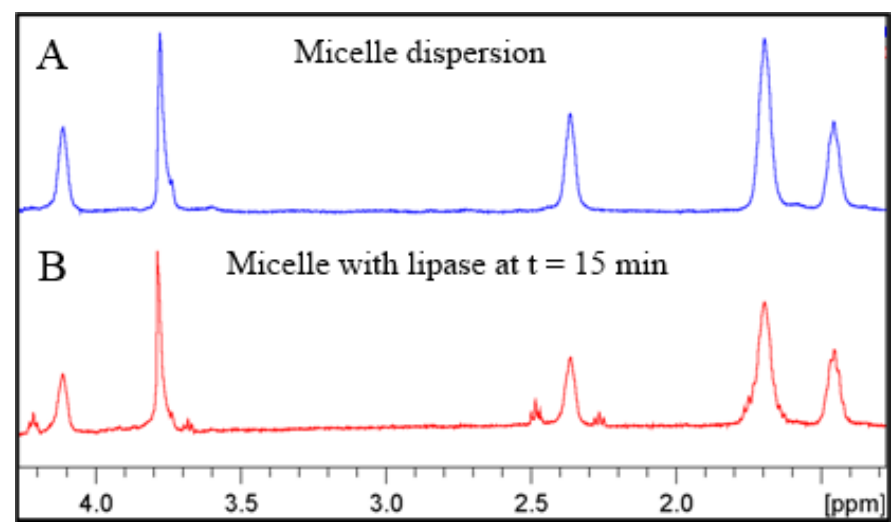

Figure 1. ${ }^{1} \mathrm{H}$ NMR $(500 \mathrm{MHz})$ of A) Aqueous dispersions of $\left[\mathrm{HO}-\mathrm{PCL}_{51}-b-\mathrm{PEO}_{32}-\mathrm{RCO}_{2}\right]^{-} \mathrm{Na}^{+}$ micelles in PBS buffer at $37^{\circ} \mathrm{C}$. B) Micelle dispersion with $P$. cepacia lipase $(1.0 \mathrm{U} / \mathrm{mL})$ after 15 min of reaction time showing the broadened micelle resonances and sharp resonances of the water soluble hydrolysis products from micelle degradation. (Detailed ${ }^{1} \mathrm{H}$ NMR assignments are given in Fig. S2).

Decline in the intensities for the broadened micelle ${ }^{1} \mathrm{H}$ NMR resonances $(\delta=2.35 \mathrm{ppm})$ as the degradation proceeds is accompanied by appearance of sharp resonances for water soluble HO-PCL $-b-\mathrm{PEO}_{32}-\mathrm{RCO}_{2} \mathrm{H}(\mathrm{n} \leq 6)$ fragments and a set of small $\mathrm{HO}-\mathrm{PCL}_{\mathrm{n}}-\mathrm{CO}_{2} \mathrm{H}(\mathrm{n} \leq 6)$ oligomers $(\delta \sim 2.27,2.48,3.70,4.22 \mathrm{ppm})$ that result from lipase catalyzed hydrolysis of HO$\mathrm{PCL}_{51}-b-\mathrm{PEO}_{32}-\mathrm{RCO}_{2} \mathrm{H}$ block copolymer chains in the micelle (Fig. 1). The PCL degradation products with different chain lengths do not influence the accuracy of the NMR integration to within our experimental capability. Our previous work demonstrates that NMR can distinguish PCL monomer and dimer in water (Fig. 2) [30]. The ratio (R) of the areas of the $\mathrm{CH}_{2}$ groups attached to an ester carbon $\left(-\mathrm{CH}_{2}-\mathrm{C}(\mathrm{O})-\mathrm{O}-, \delta \sim 2.48 \mathrm{ppm}\right)$ to that for terminal $-\mathrm{CH}_{2}-\mathrm{CO}_{2} \mathrm{H}(\delta=$ $2.27 \mathrm{ppm}$ ) gives the average number of caprolactone units (n) in the $\mathrm{HO}-\mathrm{PCL}_{\mathrm{n}}-\mathrm{CO}_{2} \mathrm{H}$ oligomers $(n=R+1)$. The average length (n) of $\mathrm{HO}-\mathrm{PCL}_{\mathrm{n}}-\mathrm{CO}_{2} \mathrm{H}$ fragment from the initial step in the lipase catalyzed hydrolytic degradation of the allyl terminated micelle is 2.9 , which is similar to the 
average $\mathrm{HO}-\mathrm{PCL}_{\mathrm{n}}-\mathrm{CO}_{2} \mathrm{H}$ fragment length of 3.3 observed for degradation of the $-\mathrm{OCH}_{3}$ terminated micelle [30].

The initial rates of micelle $(\mathrm{M})$ degradation $\left(\mathrm{V}_{\mathrm{o}}=-\mathrm{d}[\mathrm{M}] / \mathrm{dt}\right)$ are approximated by the change in micelle concentration during the first 10 minutes of reaction as evaluated from the integrated ${ }^{1} \mathrm{H}$ NMR intensities for the micelle $\mathrm{CH}_{2}$ hydrogens ( $\delta=2.35 \mathrm{ppm}$ ) (Fig. 1). The relative initial rates $\left(\mathrm{V}_{\mathrm{o}}\right)$ for the neutral corona micelle from $\mathrm{HO}-\mathrm{PCL}_{51}-b-\mathrm{PEO}_{32}-\mathrm{CH}_{2} \mathrm{CH}=\mathrm{CH}_{2}\left(\mathrm{~V}_{\mathrm{o}}=\right.$ $\left.6.0(.5) \times 10^{-4} \mathrm{mg} / \mathrm{mL} / \mathrm{s}\right)$ and the positively charged corona micelles from $\left[\mathrm{HO}-\mathrm{PCL}_{44}-b-\mathrm{PEO}_{32}-\right.$ $\left.\mathrm{RNH}_{3}\right]^{+} \mathrm{Cl}^{-}\left(\mathrm{V}_{\mathrm{o}}=5.2(.5) \times 10^{-4} \mathrm{mg} / \mathrm{mL} / \mathrm{s}\right)$ are substantially larger than the initial rates for micelles with negatively charged corona from $\left[\mathrm{HO}-\mathrm{PCL}_{51}-b-\mathrm{PEO}_{32}-\mathrm{RCO}_{2}\right]^{-} \mathrm{Na}^{+}\left(\mathrm{V}_{0}=2.3(.2) \times 10^{-4}\right.$ $\mathrm{mg} / \mathrm{mL} / \mathrm{s})$ (Fig. 2A).

\subsubsection{Rate of micelle degradation as a function of the initial enzyme concentration}

The influence of the initial enzyme concentration $\left(\left[\mathrm{E}_{0}\right]\right)$ on the kinetics of micelle degradation and the dependence of the initial rate $\left(\mathrm{V}_{0}\right)$ on $\left[\mathrm{E}_{0}\right]$ are shown in Fig. 3. The rate of micelle degradation is observed to vary linearly with $\left[E_{0}\right]$ in the lower enzyme concentration regime used in this study $\left(-\mathrm{d}[\mathrm{M}] / \mathrm{dt}=\mathrm{k}[\mathrm{M}]^{0}\left[\mathrm{E}_{\mathrm{o}}\right]^{1}\right)$ which is consistent with the mechanism in Scheme 1. 


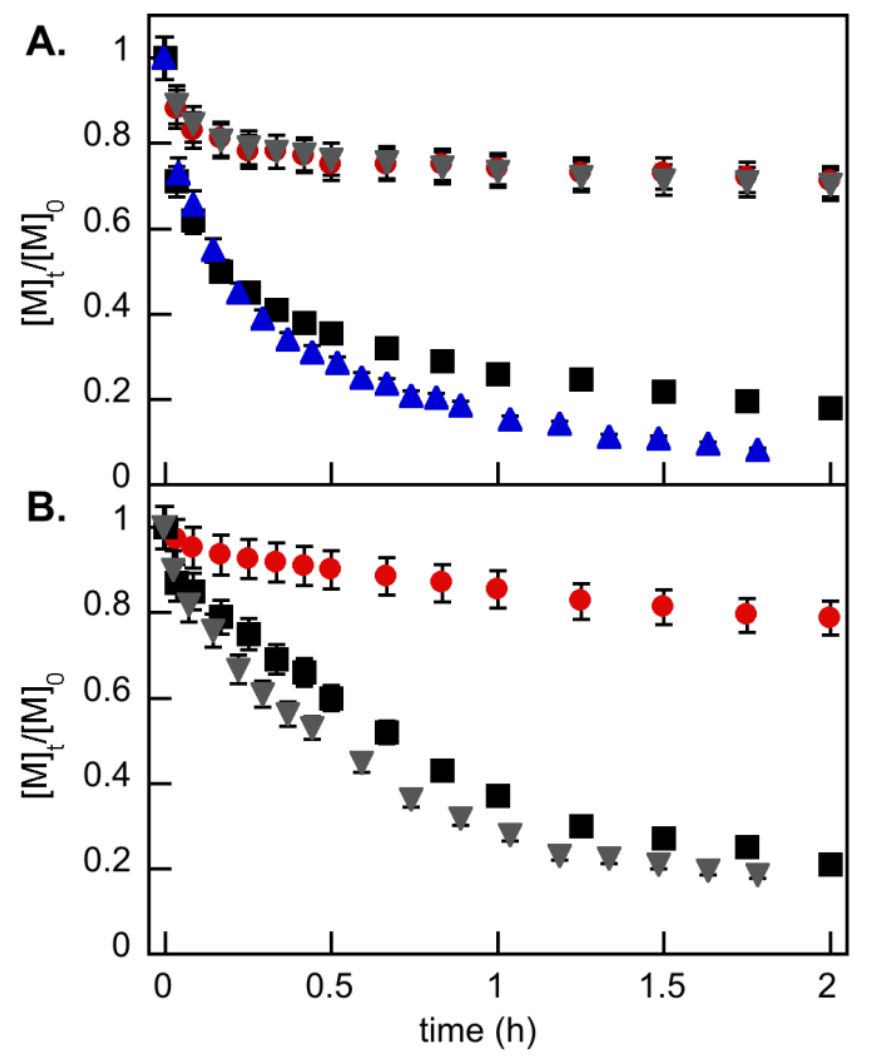

Figure 2. (A) Kinetic plots and simulations for the commercial P. cepacia lipase $(1.0 \mathrm{U} / \mathrm{mL})$ catalyzed degradation of a series of block copolymer micelles in aqueous PBS $\left(\mathrm{T}=37^{\circ} \mathrm{C}\right)$ using integration of the micelle ${ }^{1} \mathrm{H}$ NMR. A) at $\mathrm{pH}=7.4\left[\mathrm{HO}-\mathrm{PCL} 51-b-\mathrm{PEO}_{32}-\mathrm{RSO}_{3}\right]^{-} \mathrm{Na}^{+}$(red circles), $\left[\mathrm{HO}-\mathrm{PCL}_{51}-b-\mathrm{PEO}_{32}-\mathrm{RCO}_{2}\right]^{-} \mathrm{Na}^{+}$(gray triangles), $\mathrm{HO}-\mathrm{PCL} 51-b-\mathrm{PEO}_{32}-\mathrm{CH}_{2} \mathrm{CH}=\mathrm{CH}_{2}$ (black squares), and $\left[\mathrm{HO}-\mathrm{PCL}_{44}-b-\mathrm{PEO}_{32}-\mathrm{RNH}_{3}\right]^{+} \mathrm{Cl}^{-}$(blue triangles) (B) at $\mathrm{pH}=4.0$ [HO-PCL $51-b$ $\left.\mathrm{PEO}_{32}-\mathrm{RSO}_{3}\right]^{-} \mathrm{Na}^{+}$(red circles), [HO-PCL $51-b-\mathrm{PEO}_{32}-\mathrm{RCO}_{2} \mathrm{H}$ ] (gray triangles), and HO-PCL $51-b$ $\mathrm{PEO}_{32}-\mathrm{CH}_{2} \mathrm{CH}=\mathrm{CH}_{2}$ (black squares). 

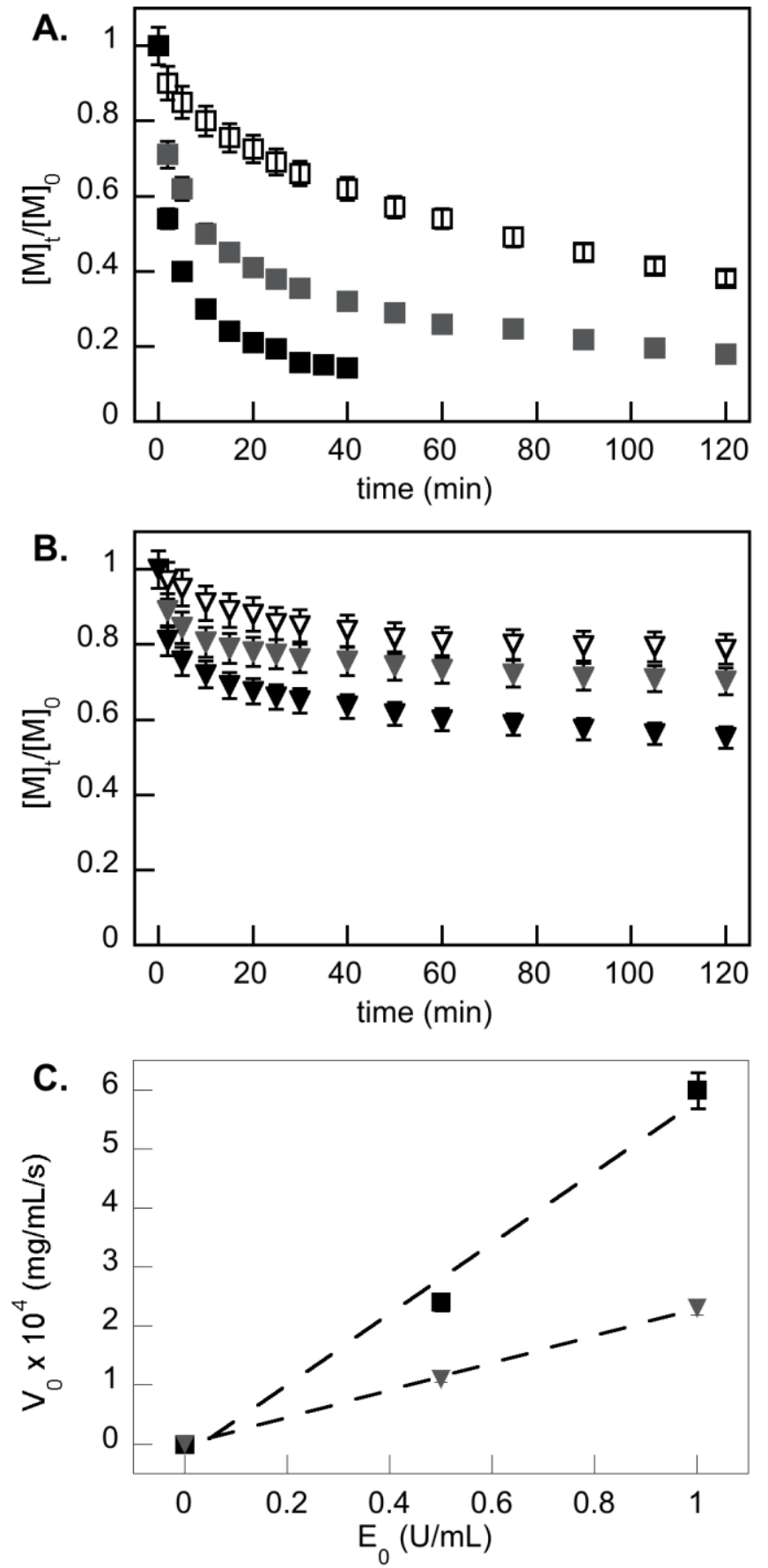

Figure 3. Kinetic plots for the degradation of (A) $\mathrm{HO}-\mathrm{PCL}_{51}-b-\mathrm{PEG}_{32}-\mathrm{CH}_{2} \mathrm{CH}=\mathrm{CH}_{2}$ micelles and (B) $\left[\mathrm{HO}-\mathrm{PCL}_{51}-b-\mathrm{PEG}_{32}-\mathrm{RCO}_{2}\right]^{-} \mathrm{Na}^{+}$micelles at lipase activities of 0.5 (open symbols), 1.0 (grey symbols) and 2.0 (black symbols) $\mathrm{U} / \mathrm{mL}, \mathrm{pH}=7.4$ and $\mathrm{T}=37^{\circ} \mathrm{C}$. (C) Linear change in the initial rate of micelle degradation with the initial enzyme concentration $\left[\mathrm{E}_{0}\right]$ for HO-PCL $\mathrm{H}_{1}-b-$ $\mathrm{PEG}_{32}-\mathrm{CH}_{2} \mathrm{CH}=\mathrm{CH}_{2}$ micelles (squares) and $\left[\mathrm{HO}-\mathrm{PCL}_{51}-b-\mathrm{PEG}_{32}-\mathrm{RCO}_{2}\right]^{-} \mathrm{Na}^{+}$micelles (triangles). 


\subsubsection{Rates of micelle degradation for sequential enzyme additions}

The kinetics for micelle degradation that results from sequential additions of two equal concentration aliquots of $P$. cepacia lipase to a $\left[\mathrm{HO}-\mathrm{PCL}_{51}-b-\mathrm{PEO}_{32}-\mathrm{RCO}_{2}\right] \mathrm{Na}^{+}$micelle dispersion are shown in Fig. 4. This experiment is carried out by making the first addition of enzyme and observing the micelle degradation with time. When the micelle degradation reaction from the first aliquot of enzyme has effectively ended a second aliquot of enzyme is added and the micelle degradation observed again until the degradation ends (Fig. 4). The initial rate of micelle degradation for addition of the first aliquot of $P$. cepacia lipase $(1.0 \mathrm{U} / \mathrm{mL})\left(\mathrm{V}_{0}(1)=2.3\right.$ $\left.(.2) \times 10^{-4} \mathrm{mg} / \mathrm{mL} / \mathrm{s}\right)$ is substantially larger than the rate observed for the addition of a second aliquot of enzyme $(1.0 \mathrm{U} / \mathrm{mL})\left(\mathrm{V}_{0}(2)=0.50(.03) \times 10^{-4} \mathrm{mg} / \mathrm{mL} / \mathrm{s}\right)$.

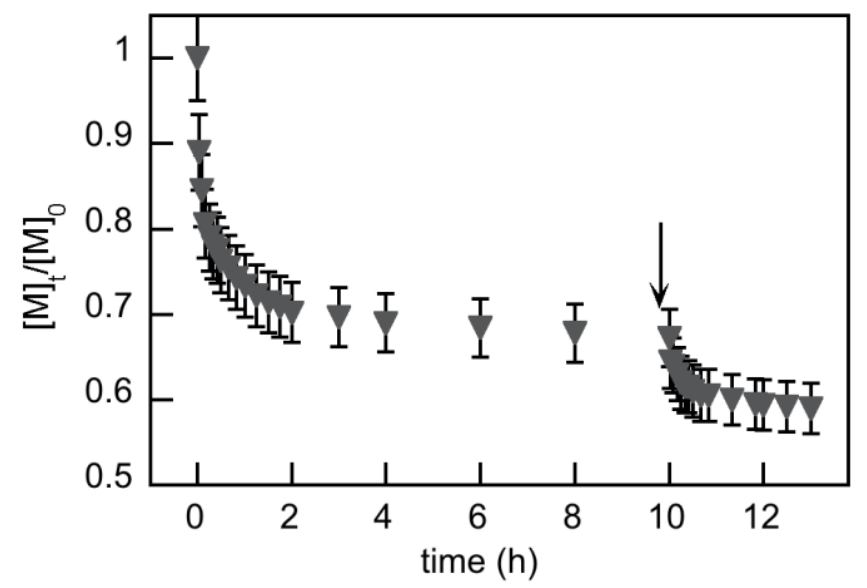

Figure 4. Degradation of $\left[\mathrm{HO}-\mathrm{PCL}_{51}-b-\mathrm{PEO}_{32}-\mathrm{RCO}_{2}\right]^{-} \mathrm{Na}^{+}$micelles that results from sequential addition of two aliquots of P.cepacia lipase $\left(1.0 \mathrm{U} / \mathrm{mL}, \mathrm{pH}=7.4\right.$ and $\left.\mathrm{T}=37^{\circ} \mathrm{C}\right)$, one at $\mathrm{t}=0 \mathrm{~h}$ and the second at $\mathrm{t}=10 \mathrm{~h} . \mathrm{V}_{0}(1)=2.3(.2) \times 10^{-4} \mathrm{mg} / \mathrm{mL} / \mathrm{s}, \mathrm{V}_{0}(2)=0.50(.03) \times 10^{-5} \mathrm{mg} / \mathrm{mL} / \mathrm{s}$.

\subsubsection{Micelle corona charge dependent P. cepacia lipase binding and catalytic degradation}

Three equal concentration samples of micelles from $\left[\mathrm{HO}-\mathrm{PCL}_{51}-\mathrm{b}-\mathrm{PEO}_{32}-\mathrm{RCO}_{2}\right]^{-} \mathrm{Na}^{+}$ were each reacted with commercial $P$. cepacia lipase $(1.0 \mathrm{U} / \mathrm{mL})$ for several hours until the 
micelle conversion had effectively stopped (Fig. 5A). At this point in time the type of lipase that binds and degrades the micelles from $\left.\mathrm{HO}-\mathrm{PCL}_{51}-\mathrm{b}-\mathrm{PEO}_{32}-\mathrm{RCO}_{2}\right]^{-} \mathrm{Na}^{+}$was fully product inhibited. One of the types of micelles (negative corona, neutral corona, or positive corona) was then added to each of the solutions with the product inhibited enzyme (Fig. 5B). The micelles from $\left[\mathrm{HO}-\mathrm{PCL}_{51}-\mathrm{b}-\mathrm{PEO}_{32}-\mathrm{RCO}_{2}\right]^{-} \mathrm{Na}^{+}$with negative corona did not react at a measureable rate, but both the micelles with neutral corona from HO-PCL $\mathrm{P}_{51}-\mathrm{b}-\mathrm{PEO}_{32}-\mathrm{CH}_{2} \mathrm{CH}=\mathrm{CH}_{2}\left(\mathrm{~V}_{0}=3.6(.2) \times\right.$ $10^{-4} \mathrm{mg} / \mathrm{mL} / \mathrm{s}$ ) and micelles with positively charged corona from [HO-PCL $\left.44-\mathrm{b}-\mathrm{PEO}_{32}-\mathrm{RNH}_{3}\right]^{+} \mathrm{Cl}^{-}$ $\left(\mathrm{V}_{0}=4.9(.5) \times 10^{-4} \mathrm{mg} / \mathrm{mL} / \mathrm{s}\right)$ were catalytically degraded at substantial rates (Fig. 5). The observed $\mathrm{V}_{0}$ values are altered by having product inhibitor substrates present from hydrolysis of the negative corona micelles at the time when the second addition of micelles is made.

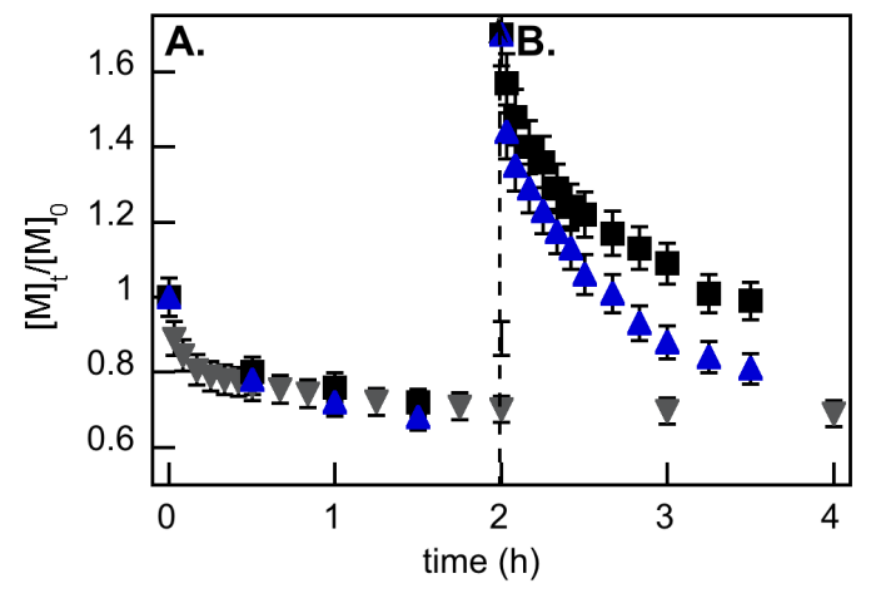

Figure 5. (A) Kinetic plots for the degradation for three samples of [HO-PCL $\left.51-b-\mathrm{PEO}_{32}-\mathrm{RCO}_{2}\right]^{-}$ $\mathrm{Na}^{+}$micelles catalyzed by commercial $P$. cepacia lipase at $\mathrm{pH} 7.4, \mathrm{~T}=37^{\circ} \mathrm{C}$ and $\mathrm{E}=1.0 \mathrm{U} / \mathrm{mL}$. (B) Kinetic plots for the degradation of micelles from [HO-PCL $\left.51-b-\mathrm{PEO}_{32}-\mathrm{RCO}_{2}\right] \mathrm{Na}^{+}$(gray triangles) $\left(\mathrm{V}_{0}=0\right), \mathrm{HO}-\mathrm{PCL}_{51}-b-\mathrm{PEO}_{32}-\mathrm{CH}_{2} \mathrm{CH}=\mathrm{CH}_{2}$ (black squares) $\left(\mathrm{V}_{0}=3.6(.2) \times 10^{-4}\right.$ $\mathrm{mg} / \mathrm{mL} / \mathrm{s})$ and $\left[\mathrm{HO}-\mathrm{PCL}_{44}-b-\mathrm{PEO}_{32}-\mathrm{RNH}_{3}\right]^{+} \mathrm{Cl}^{-}$(blue triangles) $\left(\mathrm{V}_{0}=4.9(.5) \times 10^{-4} \mathrm{mg} / \mathrm{mL} / \mathrm{s}\right)$ that were added to the three samples resulting from (A). 


\subsection{Lipase isoforms}

\subsubsection{Observation of multiple P. cepacia lipase isoforms by $2 D$ gel electrophoresis}

Samples of $P$. cepacia lipase obtained from commercial sources were examined by two dimensional electrophoresis (2DE). Separation of the enzyme samples by molecular weight in one dimension and by isoelectric point in the second direction revealed six distinct isoforms of $P$. cepacia lipase (Fig. 6). The values for the isoelectric points (pI) and isoform abundances are given in Fig. 6. The P. cepacia lipase isoforms are not resolved by mass because of similar molecular weights (33(2) kD), but the isoforms are clearly separated in the second dimension by virtue of having different $\mathrm{pI}$ values. Denaturing PAGE [32] also was unable to separate the $P$. cepacia lipase isoforms because of the small range of molecular weights.

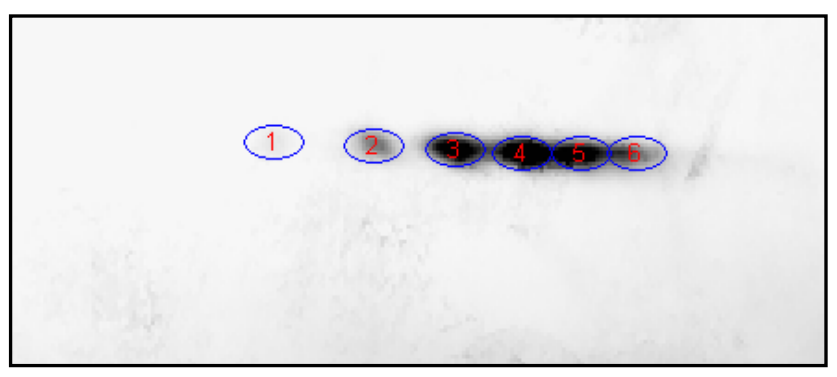

Figure 6. Resolution of $P$. cepacia lipase isoforms by $2 \mathrm{D}$ electrophoresis. Separation was according to molecular weight (top to bottom) and $\mathrm{pI}$ (left to right, $\mathrm{pI} \sim 4.0$ to 7.0 ). Estimated $\mathrm{pI}$ and abundance values for the six $P$. cepacia lipase isoforms are 1$) \mathrm{pI}=5.45(4 \%) 2) \mathrm{pI}=5.6$ $(11 \%) 3) \mathrm{pI}=5.7(21 \%) 4) \mathrm{pI}=5.8(26 \%) 5) \mathrm{pI}=5.9(23 \%) 6) \mathrm{pI}=6.0(15 \%)$.

\subsubsection{Enrichment of a commercial P. cepacia lipase sample}

The commercial P. cepacia lipase contains less than $1 \%$ protein and $>99 \%$ non-protein solids [32]. Trituration with $1.5 \mathrm{M}\left(\mathrm{NH}_{4}\right)_{2} \mathrm{SO}_{4}$ in $10 \mathrm{mM}$ phosphate buffer $(\mathrm{pH}=7)$ effectively removes many of the contaminant proteins and non-protein substances. Hydrophobic interaction 
chromatography further resolved the lipase protein into two overlapping peaks [32]. Early column fractions were enriched in an apparently slightly lighter species, which was the minority species, and later fractions were relatively enriched in an apparently slightly heavier species, which was the majority species. Conditions for complete separation have not yet been identified. These proteins have lipase catalytic activity and also sufficiently similar hydrophobicity and size that hydrophobic interaction chromatography and denaturing gel electrophoresis methods have thus far been ineffective in achieving their complete separation.

The enriched lipase solutions from the column were diluted to an enzyme activity $(\sim 0.9$ $\mathrm{U} / \mathrm{mL}$ ) convenient for evaluating the micelle degradation kinetics. The $P$. cepacia lipase was reacted with micelles from $\mathrm{HO}-\mathrm{PCL}_{51}-b-\mathrm{PEO}_{32}-\mathrm{CH}_{2} \mathrm{CH}=\mathrm{CH}_{2}$ and $\left[\mathrm{HO}-\mathrm{PCL}_{51}-b-\mathrm{PEO}_{32}-\mathrm{RCO}_{2}\right]^{-}$ $\mathrm{Na}^{+}$and the kinetics are shown in Fig. 7. The ratio of measured initial rates $(5.0 / 0.6)\left(\mathrm{V}_{\mathrm{o}}(\mathrm{HO}-\right.$ $\left.\mathrm{PCL}_{51}-b-\mathrm{PEO}_{32}-\mathrm{CH}_{2} \mathrm{CH}=\mathrm{CH}_{2}\right)=5.0 \times 10^{-4} \mathrm{mg} / \mathrm{mL} / \mathrm{s} ; \mathrm{V}_{\mathrm{o}}\left(\left[\mathrm{HO}-\mathrm{PCL}_{51}-b-\mathrm{PEO}_{32}-\mathrm{RCO}_{2}\right]^{-} \mathrm{Na}^{+}\right)=$ $\left.0.60 \times 10^{-4} \mathrm{mg} / \mathrm{mL} / \mathrm{s}\right)$ is substantially larger than the corresponding ratio $(6.0 / 2.3)$ prior to purification.

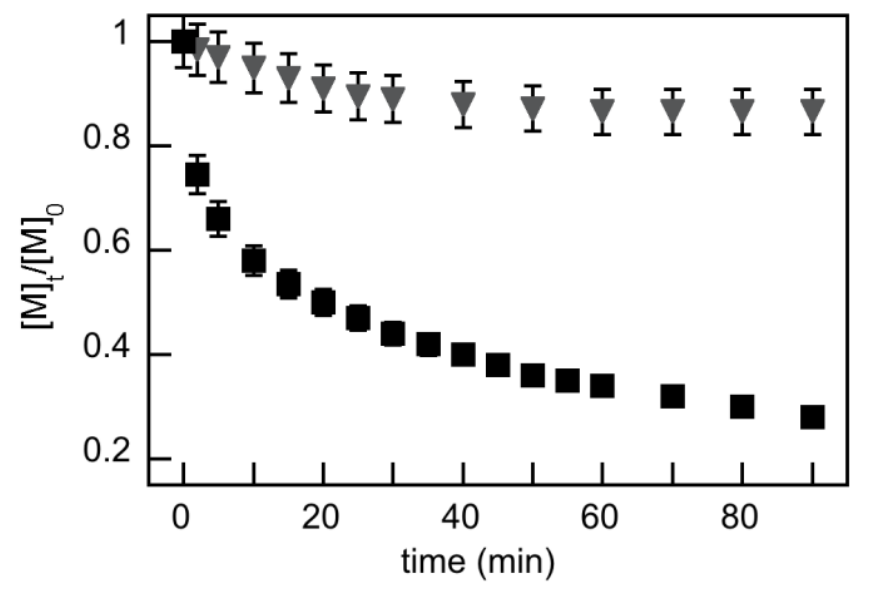

Figure 7. Kinetic plots for the degradation of $\left[\mathrm{HO}-\mathrm{PCL}_{51}-b-\mathrm{PEO}_{32}-\mathrm{RCO}_{2}^{-}\right]^{-} \mathrm{Na}^{+}$micelles (gray triangles) and of $\mathrm{HO}-\mathrm{PCL}_{51}-b-\mathrm{PEO}_{32}-\mathrm{CH}_{2} \mathrm{CH}=\mathrm{CH}_{2}$ micelles (black squares) by $P$. cepacia lipase enriched by partial resolution using a hydrophobic interaction column. $(\mathrm{E} \sim 1.0 \mathrm{U} / \mathrm{mL}, \mathrm{pH} 7.4, \mathrm{~T}$ $=37^{\circ} \mathrm{C}$ ) 


\section{Discussion}

4.1. Comparison of the general reaction characteristics of micelles with neutral, positively and negatively charged groups on the corona

Addition of $P$. cepacia lipase to dispersions of $\left[\mathrm{HO}-\mathrm{PCL}_{51}-\mathrm{b}-\mathrm{PEO}_{32}-\mathrm{RCO}_{2}\right]^{-} \mathrm{Na}^{+}$micelles in aqueous PBS buffer $\left(\mathrm{pH} 7.4, \mathrm{~T}=37^{\circ} \mathrm{C}\right)$ results in the hydrolytic degradation of micelles that are conveniently followed by ${ }^{1} \mathrm{H}$ NMR (Fig. 1B). Decline in the intensities for the broadened

micelle ${ }^{1} \mathrm{H}$ NMR resonances $(\delta=2.35 \mathrm{ppm})$ as the degradation proceeds is accompanied by appearance of sharp resonances for water soluble $\mathrm{HO}-\mathrm{PCL}_{\mathrm{n}}-\mathrm{b}-\mathrm{PEO}_{32}-\mathrm{RCO}_{2}{ }^{-}(\mathrm{n} \leq 6)$ fragments and a set of small HO- $-\mathrm{PCL}_{\mathrm{n}}-\mathrm{CO}_{2}{ }^{-}(\mathrm{n} \leq 6)$ oligomers $(\delta \sim 2.27,2.48,3.70,4.22 \mathrm{ppm})$ that result from lipase catalyzed hydrolysis of $\mathrm{HO}-\mathrm{PCL}_{51}-\mathrm{b}-\mathrm{PEO}_{32}-\mathrm{RCO}_{2}{ }^{-}$block copolymer chains in the micelle (Fig. 1). The ratio (R) of the areas of the $\mathrm{CH}_{2}$ groups attached to an ester carbon $\left(-\mathrm{CH}_{2}-\right.$ $\mathrm{C}(\mathrm{O})-\mathrm{O}-, \delta \sim 2.48 \mathrm{ppm})$ to that for terminal $-\mathrm{CH}_{2}-\mathrm{CO}_{2}^{-}(\delta=2.27 \mathrm{ppm})$ gives the average number of caprolactone units (n) in the PCL oligomers $(n=R+1)$. The average length (n) of HO-PCL $\mathrm{CO}_{2}^{-}$fragment from the initial step in the lipase catalyzed hydrolytic degradation of the allyl terminated micelle is $2.8-3.0$ which is similar to the average $\mathrm{HO}-\mathrm{PCL}_{\mathrm{n}}-\mathrm{CO}_{2}^{-}$fragment length of 3.2-3.4 observed for degradation of the $-\mathrm{CO}_{2}{ }^{-}$terminated micelle (Figs. 1 and S2). ${ }^{1} \mathrm{H}$ NMR provides a convenient and effective technique to obtain detailed information that simultaneously determines the composition of the micelle and the products from polymer hydrolysis as the degradation process proceeds. 


\subsubsection{Kinetics of lipase catalyzed hydrolytic degradation of micelles with neutral and charged}

groups on the terminus of the block copolymer micelle corona

Kinetic plots for the P. cepacia lipase catalyzed hydrolytic degradation of micelles from HO-PCL $51-b-\mathrm{PEO}_{32}-\mathrm{CH}_{2} \mathrm{CH}=\mathrm{CH}_{2}, \quad\left[\mathrm{HO}-\mathrm{PCL}_{51}-\mathrm{b}-\mathrm{PEO}_{32}-\mathrm{RCO}_{2}\right]^{-} \mathrm{Na}^{+}, \quad$ [HO-PCL $51-\mathrm{b}-\mathrm{PEO}_{32}-$ $\left.\mathrm{RSO}_{3}\right]^{-} \mathrm{Na}^{+}$and $\left[\mathrm{HO}-\mathrm{PCL}_{44}-\mathrm{b}-\mathrm{PEO}_{32}-\mathrm{RNH}_{3}\right]^{+} \mathrm{Cl}^{-}\left(\mathrm{R}=\left(\mathrm{CH}_{2}\right)_{3} \mathrm{~S}_{\left.\left(\mathrm{CH}_{2}\right)_{2}-\right)}\right.$ block copolymers are given in Fig. 2. Interpretation of the general features of the kinetics of $P$. cepacia lipase catalyzed degradations of $\mathrm{HO}-\mathrm{PCL}_{\mathrm{n}}-\mathrm{b}-\mathrm{PEO}_{32}-\mathrm{X}$ block copolymer micelles are guided by prior results from detailed kinetic-mechanistic studies for the $P$. cepacia lipase catalyzed degradation of closely related $\mathrm{HO}-\mathrm{PCL}_{60}-\mathrm{b}-\mathrm{PEO}_{45}-\mathrm{OMe}$ block copolymer micelles [30]. The lipase enzyme catalysis involves an initial step of lipase-micelle complex formation that has a sufficiently large equilibrium constant so that when the concentration of micelle particles is greater than the initial enzyme concentration then effectively all of the enzyme molecules are bound in an enzymemicelle complex $(\mathrm{E}+\mathrm{M} \rightleftharpoons \mathrm{E}-\mathrm{M})$. Kinetic simulations of the experimental micelle degradation kinetics require a very large equilibrium constant for enzyme -micelle binding $\left(\mathrm{k}>10^{11} ; \mathrm{E}+\mathrm{M} \rightarrow\right.$ E-M) in order to fit the experimental data. Details for the kinetics simulations are found in the SI. The enzyme-micelle complex in the subsequent step generates products from ester hydrolysis (E$\mathrm{M} \rightleftharpoons \mathrm{P}+\mathrm{E})($ Scheme 1). Each of the lipase catalyzed micelle degradations that were evaluated (Fig. 2) has a relatively large initial rate, but as the micelle degradation proceeds the reaction slows down much faster than would be expected based on the rate law $\left(-\mathrm{d}[\mathrm{M}] / \mathrm{dt}=\mathrm{k}[\mathrm{M}]^{0}\left[\mathrm{E}_{\mathrm{o}}\right]^{1}\right)$ and the initial rates in a manner consistent with loss of enzyme activity. A closely related decline in effective lipase activity observed for the $P$. cepacia lipase catalyzed degradation of micelles from $\mathrm{HO}-\mathrm{PCL}_{60}-\mathrm{b}-\mathrm{PEO}_{45}-\mathrm{OMe}$ was shown to result from enzyme inhibition by water soluble micelle degradation products of the form $\mathrm{MeO}-\mathrm{PEO}_{45}-\mathrm{PCL}_{\mathrm{n}}-\mathrm{OH}(\mathrm{n} \leq 6)$. The MeO-PEO $45-b-$ 
$\mathrm{PCL}_{\mathrm{n}} \mathrm{OH}$ enzyme inhibitor has a short PCL ester substrate that competes for occupying the lipase Ser-His-Asp triad catalytic center [51-53] and a $\mathrm{PEO}_{45}$ chain that may contribute to the lipase-micelle binding. The MeO-PEO $45-\mathrm{PCL}_{\mathrm{n}}-\mathrm{OH}$ degradation product of $\mathrm{HO}-\mathrm{PCL}_{\mathrm{n}} \leq 6-\mathrm{b}-\mathrm{PEO}_{45}-$ OMe was directly shown to be an efficient lipase catalyst inhibitor[30] and the closely related HO-PCL $L_{\mathrm{n} \leq 6}-\mathrm{b}-\mathrm{PEO}_{32}-\mathrm{RX} \quad\left(\mathrm{R}=\left(\mathrm{CH}_{2}\right)_{3} \mathrm{~S}\left(\mathrm{CH}_{2}\right)_{2}-\right) ; \mathrm{X}=-\mathrm{CO}_{2}^{-},-\mathrm{SO}_{3}^{-}$and $-\mathrm{NH}_{3}{ }^{+}$degradation products from the micelles used in this study also function as effective lipase inhibitors. Micelles derived from $\mathrm{HO}-\mathrm{PCL}_{51}-\mathrm{b}-\mathrm{PEO}_{32}-\mathrm{CH}_{2} \mathrm{CH}=\mathrm{CH}_{2}$ and $\left[\mathrm{HO}-\mathrm{PCL}_{44}-\mathrm{b}-\mathrm{PEO}_{32}-\mathrm{RNH}_{3}\right]^{+} \mathrm{Cl}^{-}$with neutral or positively charged groups on the corona are catalytically degraded by commercial $P$. cepacia lipase to a much higher conversion prior to full product inhibition than micelles from [HO-PCL51-b-PEO $\left.32-\mathrm{RCO}_{2}\right]^{-} \mathrm{Na}^{+}$with negatively charged corona (Fig. 2).

The initial rates of micelle $(\mathrm{M})$ degradation $\left(\mathrm{V}_{\mathrm{o}}=-\mathrm{d}[\mathrm{M}] / \mathrm{dt}\right)$ are approximated by the change in micelle concentration during the first 10 minutes of reaction as evaluated from the integrated ${ }^{1} \mathrm{H}$ NMR intensities for the micelle $\mathrm{CH}_{2}$ hydrogens $(\delta=2.35 \mathrm{ppm})$ (Fig. 1). The relative initial rates $\left(\mathrm{V}_{\mathrm{o}}\right)$ for the neutral corona micelle from $\mathrm{HO}-\mathrm{PCL}_{51}-\mathrm{b}-\mathrm{PEO}_{32}-\mathrm{CH}_{2} \mathrm{CH}=\mathrm{CH}_{2}$ $\left(\mathrm{V}_{\mathrm{o}}=6.0(.5) \times 10^{-4} \mathrm{mg} / \mathrm{mL} / \mathrm{s}\right)$ and the positively charged corona micelles from [HO-PCL44-b$\left.\mathrm{PEO}_{32}-\mathrm{RNH}_{3}\right]^{+} \mathrm{Cl}^{-}\left(\mathrm{V}_{\mathrm{o}}=5.2(.5) \times 10^{-4} \mathrm{mg} / \mathrm{mL} / \mathrm{s}\right)$ are substantially larger than the initial rates for micelles with negatively charged corona from $\left[\mathrm{HO}-\mathrm{PCL}_{51}-\mathrm{b}-\mathrm{PEO}_{32}-\mathrm{RCO}_{2}\right]^{-} \mathrm{Na}^{+}\left(\mathrm{V}_{0}=2.3(.2) \times\right.$ $10^{-4} \mathrm{mg} / \mathrm{mL} / \mathrm{s}$ ) (Fig. 2).

\subsubsection{Kinetics for micelle degradation from varying the initial enzyme concentration}

The influence of the initial enzyme concentration $\left(\left[\mathrm{E}_{0}\right]\right)$ on the kinetics of micelle degradation and the dependence of the initial rate $\left(\mathrm{V}_{0}\right)$ on $\left[\mathrm{E}_{0}\right]$ are shown in Fig. 3. The rate of micelle degradation is observed to vary linearly with $\left[\mathrm{E}_{0}\right]$ in the lower enzyme concentration 
regime used in this study $\left(-\mathrm{d}[\mathrm{M}] / \mathrm{dt}=\mathrm{k}[\mathrm{M}]^{0}\left[\mathrm{E}_{\mathrm{o}}\right]^{1}\right)$ which is consistent with the mechanism in Scheme 1.

Evidence for enzyme product inhibition from kinetic studies comes from sequential additions of $P$. cepacia lipase to aqueous dispersions of $\left[\mathrm{HO}-\mathrm{PCL}_{51}-\mathrm{b}-\mathrm{PEO}_{32}-\mathrm{RCO}_{2}\right]^{-} \mathrm{Na}^{+}$ micelles. The kinetics for micelle degradation that results from sequential additions of two equal concentration aliquots of $P$. cepacia lipase to a $\left[\mathrm{HO}-\mathrm{PCL}_{51}-\mathrm{b}-\mathrm{PEO}_{32}-\mathrm{RCO}_{2}{ }^{-}\right] \mathrm{Na}^{+}$micelle dispersion are shown in Fig. 4. When the micelle particles are in excess over the number of enzyme molecules, the degradation is zero order in micelle concentration ([M]) and first order in the initial enzyme concentration $\left(\left[\mathrm{E}_{0}\right]\right)$ which is equivalent to first order in the enzyme-micelle complex $[\mathrm{EM}]\left(-\mathrm{d}[\mathrm{M}] / \mathrm{dt}=\mathrm{k}[\mathrm{M}]^{0}\left[\mathrm{E}_{0}\right]^{1}=\mathrm{k}[\mathrm{M}]^{0}[\mathrm{EM}]^{1}\right)$. Sequential additions of aliquots of equal activity of enzyme would give equal quantities of micelle degradation in the absence of enzyme product inhibition.

The initial rate of micelle degradation for addition of the first aliquot of $P$. cepacia lipase $(1.0 \mathrm{U} / \mathrm{mL})\left(\mathrm{V}_{0}(1)=2.3(.2) \times 10^{-4} \mathrm{mg} / \mathrm{mL} / \mathrm{s}\right)$ is substantially larger than the rate observed for the addition of a second aliquot of enzyme $(1.0 \mathrm{U} / \mathrm{mL})\left(\mathrm{V}_{0}(2)=0.50(.03) \times 10^{-4} \mathrm{mg} / \mathrm{mL} / \mathrm{s}\right)$ which reflects the inhibition of enzyme activity from products $\left(\left[\left(\mathrm{HO}-\mathrm{PCL}_{\mathrm{n}}-\mathrm{b}-\mathrm{PEO}_{32}-\mathrm{RCO}_{2}\right]^{-} \mathrm{Na}^{+}(\mathrm{n} \leq\right.\right.$ 6)) formed from the micelle degradation by reaction of the first aliquot of enzyme (Fig. 4).

\subsubsection{Kinetics of lipase catalyzed hydrolytic degradation of block copolymer micelles at a series} of pH values using commercial P. cepacia lipase

Kinetics of $P$. cepacia lipase enzyme catalyzed degradation for the diblock copolymer micelles of $\mathrm{HO}-\mathrm{PCL}_{51}-\mathrm{b}-\mathrm{PEO}_{32}-\mathrm{CH}_{2} \mathrm{CH}=\mathrm{CH}_{2}$, [HO-PCL51-b-PEO $\left.32-\mathrm{RCO}_{2}\right]^{-} \mathrm{Na}^{+}$, [HO-PCL51-b$\left.\mathrm{PEO}_{32}-\mathrm{RSO}_{3}\right]^{-} \mathrm{Na}^{+}$at constant temperature $\left(\mathrm{T}=37^{\circ} \mathrm{C}\right)$ and initial lipase activity $(\mathrm{E})$ equal to 1.0 
$\mathrm{U} / \mathrm{mL}$ are shown at a series of $\mathrm{pH}$ values in Fig. 2. At a $\mathrm{pH}$ values of 7.4 and higher the micelles from $\left[\mathrm{HO}-\mathrm{PCL}_{51}-\mathrm{b}-\mathrm{PEO}_{32}-\mathrm{RCO}_{2}\right]^{-} \mathrm{Na}^{+}$and $\left[\mathrm{HO}-\mathrm{PCL}_{51}-\mathrm{b}-\mathrm{PEO}_{32}-\mathrm{RSO}_{3}\right]^{-} \mathrm{Na}^{+}$have a negatively charged corona and thus should exclusively react with the lipase L(I) which is distinctly different from micelles of $\mathrm{HO}-\mathrm{PCL}_{51}-\mathrm{b}-\mathrm{PEO}_{32}-\mathrm{CH}_{2} \mathrm{CH}=\mathrm{CH}_{2}$ which have neutral corona and react with both lipases L(I) and L(II) (Fig. 2). When the $\mathrm{pH}$ is reduced to 4.0 the carboxylate anion end groups become protonated to neutral carboxylic acid groups $\left(-\mathrm{CO}_{2} \mathrm{H}\right)$, but the sulfonate groups remain anionic $\left(-\mathrm{SO}_{3}{ }^{-}\right)$. The enzyme will also undergo protonation equilibria and will be more extensively protonated at $\mathrm{pH}$ 4.0. Some activity differences are indeed observed, but the micelles with carboxylic acid terminated corona at $\mathrm{pH}$ of 4.0 react with both classes of lipases L(I) and $\mathrm{L}$ (II) and closely emulate the reactivity of micelles from $\mathrm{HO}-\mathrm{PCL}_{51}-\mathrm{b}-\mathrm{PEO}_{32}-\mathrm{CH}_{2} \mathrm{CH}=\mathrm{CH}_{2}$ (Fig. 2), but the micelles with $-\mathrm{SO}_{3}{ }^{-}$capped corona remain anionic at a $\mathrm{pH}$ of 4.0 and only react with the L(I) lipases (Fig. 2). The observed pattern of P. cepacia lipase(s) degradation of micelles from $\mathrm{HO}-\mathrm{PCL}_{51}-\mathrm{b}-\mathrm{PEO}_{32}-\mathrm{CH}_{2} \mathrm{CH}=\mathrm{CH}_{2}$, [HO-PCL $\left.51-b-\mathrm{PEO}_{32}-\mathrm{RCO}_{2}\right]^{-} \mathrm{Na}^{+}$and $\left[\mathrm{HO}-\mathrm{PCL}_{51}-\mathrm{b}-\right.$ $\left.\mathrm{PEO}_{32}-\mathrm{RSO}_{3}{ }^{-}\right] \mathrm{Na}^{+}$as the $\mathrm{pH}$ changes provide confirmatory evidence that the commercial $P$. cepacia lipase(s) contains several lipases where one of the types of lipases (L(I)) catalyze degradation of micelles with negatively charged corona, and both types of lipases L(I) and L(II) catalyze degradation of micelles with neutral corona (Fig. 2).

\subsection{Micelle corona charge dependent P. cepacia lipase catalysis}

\subsubsection{Product inhibited enzyme used to detect micelle corona charge dependent catalysis}

Kinetics for lipase catalyzed degradation of $\left[\mathrm{HO}-\mathrm{PCL}_{51}-\mathrm{b}-\mathrm{PEO}_{32}-\mathrm{RCO}_{2}\right]^{-} \mathrm{Na}^{+}$and $\mathrm{HO}-$ PCL $51-b-\mathrm{PEO}_{32}-\mathrm{CH}_{2} \mathrm{CH}=\mathrm{CH}_{2}$ micelles by solutions where the $\mathrm{L}(\mathrm{I})$ lipase that degrades micelles 
from [HO-PCL $\left.51-b-\mathrm{PEO}_{32}-\mathrm{RCO}_{2}\right]^{-} \mathrm{Na}^{+}$is fully product inhibited are illustrated in Fig. 5. Micelles from $\left[\mathrm{HO}-\mathrm{PCL}_{51}-\mathrm{b}-\mathrm{PEO}_{32}-\mathrm{RCO}_{2}\right]^{-} \mathrm{Na}^{+}$with negatively charged corona are degraded catalytically by the commercial $P$. cepacia lipase with a substantially smaller initial rate $\left(\mathrm{V}_{0}\right)$ and much smaller conversion before obtaining full enzyme inhibition than micelles with neutral and positively charged groups on the corona (Fig. 2). Both of these differences could be understood if only a fraction of the P. cepacia lipase were active for degradation of the micelle from [HOPCL $\left.51-b-\mathrm{PEO}_{32}-\mathrm{RCO}_{2}\right]^{-} \mathrm{Na}^{+}$which has a negatively charged corona terminus. This possibility was examined by testing for the presence of residual active enzyme after the $P$. cepacia lipase enzyme that degrades micelles from $\left[\mathrm{HO}-\mathrm{PCL}_{51}-\mathrm{b}-\mathrm{PEO}_{32}-\mathrm{RCO}_{2}{ }^{-}\right] \mathrm{Na}^{+}$is fully product inhibited (Fig. 5).

Three equal concentration samples of micelles from $\left[\mathrm{HO}-\mathrm{PCL}_{51}-\mathrm{b}-\mathrm{PEO}_{32}-\mathrm{RCO}_{2}\right]^{-} \mathrm{Na}^{+}$ were each reacted with commercial $P$. cepacia lipase $(1.0 \mathrm{U} / \mathrm{mL})$ for several hours until the micelle conversion had effectively stopped (Fig. 5A). One of the corona substituted micelle derivatives from among $\left[\mathrm{HO}-\mathrm{PCL}_{51}-\mathrm{b}-\mathrm{PEO}_{32}-\mathrm{RCO}_{2}\right] \mathrm{Na}^{+}, \mathrm{HO}-\mathrm{PCL}_{51}-\mathrm{b}-\mathrm{PEO}_{32}-\mathrm{CH}_{2} \mathrm{CH}=\mathrm{CH}_{2}$ and [HO-PCL44-b- $\left.\mathrm{PEO}_{32}-\mathrm{RNH}_{3}\right]^{+} \mathrm{Cl}^{-}$was then added to each of the solutions with the product inhibited enzyme (Fig. 5B). The micelles from $\left.\mathrm{HO}-\mathrm{PCL}_{51}-\mathrm{b}-\mathrm{PEO}_{32}-\mathrm{RCO}_{2}\right]^{-} \mathrm{Na}^{+}$with a negatively charged corona did not react at a measureable rate, but the micelles with neutral corona from HO-PCL ${ }_{51}-\mathrm{b}-\mathrm{PEO}_{32}-\mathrm{CH}_{2} \mathrm{CH}=\mathrm{CH}_{2}$ and positively charged corona from [HO-PCL $44-\mathrm{b}-\mathrm{PEO}_{32}-$ $\left.\mathrm{RNH}_{3}\right]^{+} \mathrm{Cl}^{-}$were both catalytically degraded at relatively large initial rates (Fig. 5).

This set of experiments demonstrates that active lipase enzymes persist in solution that are able to catalyze degradation of micelles with neutral and positively charged corona but not micelles with negatively charged corona after the type of lipase enzymes that catalyzes the degradation of micelles from $\left[\mathrm{HO}-\mathrm{PCL}_{51}-\mathrm{b}-\mathrm{PEO}_{32}-\mathrm{RCO}_{2}\right]^{-} \mathrm{Na}^{+}$are fully product inhibited (Fig. 
5). This set of results (Fig. $5 ; 3.1 .3$ ) clearly demonstrates that the commercially obtained $P$. cepacia lipase(s) that was believed to be a single lipase enzyme must actually contain at least two types of $P$. cepacia lipase isoforms that differ dramatically in reactivity with micelles where the terminus of the micelle corona has electronically charged groups.

The observed relative initial rates for micelle degradations $\left(\mathrm{V}_{\mathrm{o}}\right)$ were interpreted assuming the presence of two classes of lipases in the commercial $P$. cepacia lipase. The rate at which active lipase $\mathrm{L}(\mathrm{II})$ degrades the micelles from HO-PCL51-b- $\mathrm{PEO}_{32}-\mathrm{CH}_{2} \mathrm{CH}=\mathrm{CH}_{2}\left(\mathrm{~V}_{0}=\right.$ $\left.3.6(.2) \times 10^{-4} \mathrm{mg} / \mathrm{mL} / \mathrm{s}\right)$ in the system where $\mathrm{L}(\mathrm{I})$ is product deactivated is decreased from the rate when both lipases are active in the initial enzyme mixture $\left(\mathrm{V}_{\mathrm{o}}=6.0(.5) \times 10^{-4} \mathrm{mg} / \mathrm{mL} / \mathrm{s}\right)$ by an amount expected for L(I) being an active catalyst for degradation of micelles with both negatively charged and neutral corona. The residual active lipase (L(II)) after L(I) is fully inhibited reacts with the micelle of $\left[\mathrm{HO}-\mathrm{PCL}_{44}-\mathrm{b}-\mathrm{PEO}_{32}-\mathrm{RNH}_{3}\right]^{+} \mathrm{Cl}^{-}\left(\mathrm{V}_{0}=4.9(.4) \times 10^{-4}\right.$ $\mathrm{mg} / \mathrm{mL} / \mathrm{s})$ with a rate that approaches that of the initial lipase mixture (L(I) $+\mathrm{L}(\mathrm{II}))\left(\mathrm{V}_{0}=5.2(.4)\right.$ $\left.\times 10^{-4} \mathrm{mg} / \mathrm{mL} / \mathrm{s}\right)$ and this result is interpreted as indicating that $\mathrm{L}(\mathrm{I})$ is ineffective as a catalyst in the degradation of micelles with a positively charged corona.

Combining the kinetic results for micelle degradations using the fully active (Fig. 2) and the anionic micelle product inhibited lipases (Fig. 5) indicate that the two observed forms of $P$. cepacia lipase manifest opposite high levels of complementary corona charge selective catalytic activity. Lipase enzyme type L(I) catalyzes degradation of micelles with negatively charged corona and do not catalytically degrade micelles with positively charged corona . Lipase type L(II) is complementary to L(I) in having a large preference for catalyzing degradation of micelles with positively charged compared to negatively charged corona. Both P. cepacia lipase 
forms L(I) and L(II) catalyze hydrolytic degradation of micelles with neutral groups $\left(-\mathrm{CH}_{2} \mathrm{CH}=\mathrm{CH}_{2} ;-\mathrm{CO}_{2} \mathrm{H}\right)$ on the corona terminus.

Biophysical evidence to support the kinetic evidence for multiple $P$. cepacia lipase isoforms was afforded by two dimensional electrophoresis (2DE). Separation by molecular weight in one dimension and by isoelectric point in the second direction revealed six distinct isoforms of $P$. cepacia lipase (Fig. 6). The pI values and abundances for these isoforms are given in Table 1. The isoforms all have an apparent molecular weight of $\sim 33 \mathrm{kD}$, but are separated in the second dimension by virtue of having different $\mathrm{pI}$ values. Because the isoforms have nearly the same molecular weight, they were not resolved by denaturing PAGE [32]. It is not yet known which isoform(s) have the kinetic behavior of L(I) and L(II), and it is also possible that not all of the detected isoforms are catalytically active towards the block copolymer micelle substrates.

When the commercial lipase was partially purified by using hydrophobic interaction chromatography, the ratio of measured initial rates for hydrolysis of the neutral versus the negative corona micelle $(5.0 / 0.6)$ is substantially larger than the corresponding ratio $(6.0 / 2.3)$ prior to purification. This result shows that the lipase (L(II)) that does not react with the micelles from $\left[\mathrm{HO}-\mathrm{PCL}_{51}-b-\mathrm{PEO}_{32}-\mathrm{RCO}_{2}^{-}\right]^{-} \mathrm{Na}^{+}$has been enriched by a factor of about 3 by the separation procedure.

4.2.2. Model for P. cepacia lipase hydrolytic degradation of block copolymer micelles with polyester cores and corona charge dependent lipase catalysis

Block copolymers of poly (ethylene glycol) (PEO) block poly ( $\varepsilon$-caprolactone) (PCL) self-assemble into core-shell micelles in water where the hydrolytically non-degradable hydrophilic PEO segment forms the exterior corona and the core contains the hydrolytically 
degradable polyester hydrophobic PCL block. The micelle corona consists of the water-soluble PEO segment, which permits stable aqueous dispersions of micelles with water insoluble hydrophobic PCL polyester cores. Lipases that catalyze hydrolysis of the assembly of polyester (PCL) segments in the micelle core probably interact with the micelle in the hydrophobic region, which subsequently guides the polyester chain into the catalytic hydrolysis center. Binding of a hydrophobic region of the micelle with the "hydrophobic trench" of the lipase enzyme is apparently strong enough such that the polyester hydrolysis and micelle degradation occur much faster than exchange of the enzyme molecule between micelles.

The strong interaction between the dispersed micelle particles and the sparingly soluble lipase is aided by the hydrophobic effect from water that effectively pushes the hydrophobic sections of the enzyme and micelle together and out away from the aqueous phase. The two types of lipase enzymes found in a commercial sample of $P$. cepacia lipase have sufficiently similar hydrophobicity and size that hydrophobic interaction chromatography and denaturing gel electrophoresis methods are ineffective in separating the isoforms. However, the two lipases have highly selective micelle degradation catalysis associated with the electronic charge carried by the micelle corona, and the corona charge dependent catalysis is thus ascribed to electronic effects in the vicinity of the catalysis center (Fig. 8) rather than bulk electronic effects of the entire enzyme molecule. The charged corona is distant from the water-hydrophobic interface where the polyester hydrolysis is thought to occur and so the corona charge effect is tentatively ascribed to a coulombic kinetic barrier to micelle-enzyme complex formation similar to that described as electrostatic steering [54]. This model further leads to expecting that the two categories of $P$. cepacia lipase isoforms may have sites with opposite net charges that influence micelle-lipase complex formation. Scheme 2 illustrates the micelle corona charge dependent 
lipase catalyzed micelle degradation for the two observed complementary P. cepacia lipases. The larger equilibrium constant for product inhibition observed for the lipase that catalyzes degradation of negative corona micelles (L(I)) suggests that the active catalyst center and adjacent hydrophobic trench have one or more sites that exhibit stronger inhibitor-lipase binding than the lipase that reacts with positively charged or neutral corona micelles.

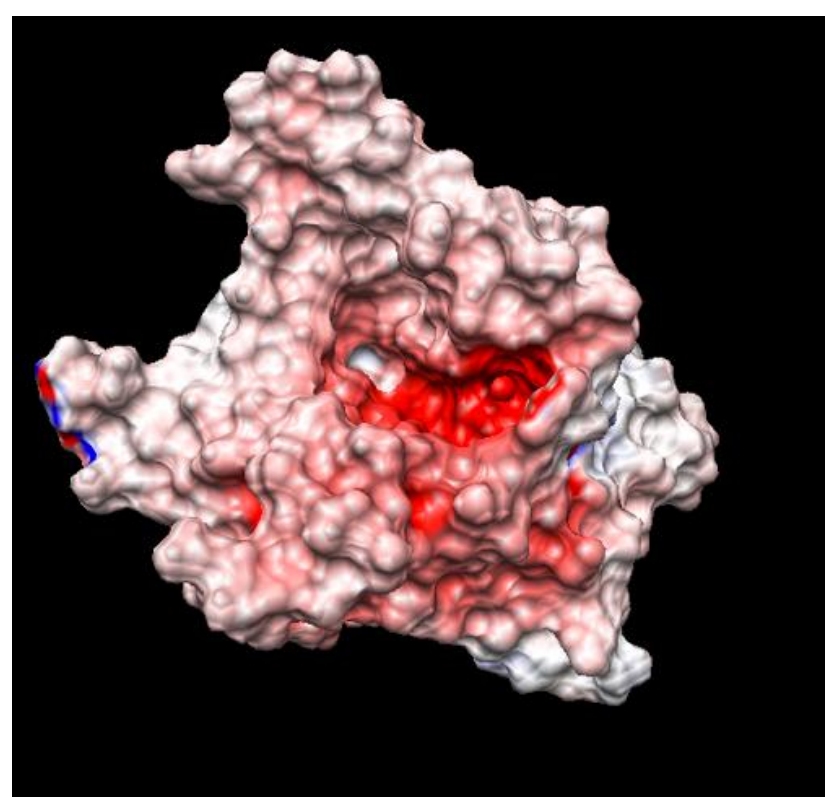

Figure 8. Surface charge map $($ red $=$ negative, blue $=$ positive $)$ generated in Chimera by using the P. cepacia lipase structure deposited as 2LIP [55]. The active site lies in a trench where modification of local charge would affect reactivity.

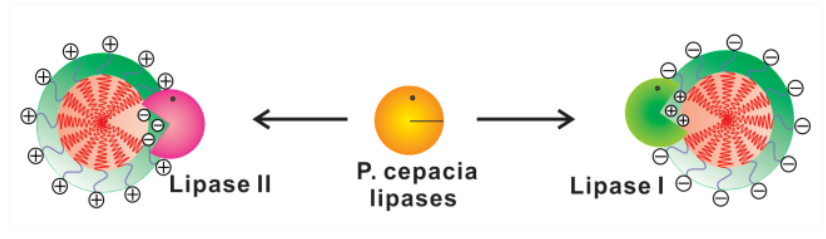

Scheme 2. Illustration of complementary micelle corona charge selective catalysis for two $P$. cepacia lipase components. 
Multiple lipase isoforms are found in other species including Candida rugosa [56] and $P$. fluorescens [57]. The genome of P. cepacia contains only one apparent lipase gene [58], and so it is likely that posttranslational modification(s) are responsible for the current different isoforms. About 40 amino acids are proteolyzed from the $\mathrm{N}$ terminus to afford the mature lipase characterized by X-ray crystallography [55, 59], but sequence analysis predicts several favorable N-terminal cleavage sites that would yield slightly shorter or longer proteins [60]. Quite large variations in cleavage site would be required to cause the variation in $\mathrm{pI}$ revealed in Fig. 7, however, and the lipase isoforms detected are too similar in size to one another for such differential N-terminal truncation to be a likely explanation. Several different types of posttranslational modifications might yield electrostatically distinct lipase components originating from the same gene. Protein modifications like phosphorylation or glycosylation would also affect protein electrostatic properties and surfaces. Identifying the molecular differences among the P. cepacia lipase isoforms and comparison of the electronic charge distributions of the hydrophobic trench and catalyst centers are high priority continuing objectives.

\section{Conclusions}

Poly (caprolactone)-poly (ethylene glycol) block copolymers (HO-PCL $\left.-b-\mathrm{PEO}_{\mathrm{m}}-\mathrm{X}\right)$ self assemble into micelles where the PEO-RX $\left(\mathrm{X}=-\mathrm{CH}_{2} \mathrm{CH}=\mathrm{CH}_{2},-\mathrm{CO}_{2}{ }^{-},-\mathrm{SO}_{3}^{-},-\mathrm{NH}_{3}{ }^{+}\right)$segment is the corona and the PCL block is the polyester core. Aqueous dispersions of these micelles function as substrates for P. cepacia lipase catalyzed hydrolysis of the polyester (PCL) core and micelle degradation through an interfacial activation process. An allyl terminated PEO block 
copolymer (HO-PCL- $b$-PEO- $\mathrm{CH}_{2} \mathrm{CH}=\mathrm{CH}_{2}$ ) is substituted to give a set of micelles that differ in having negatively charged $\left(-\mathrm{CO}_{2}^{-}\right)$and positively charged $\left(-\mathrm{NH}_{3}{ }^{+}\right)$micelle corona. The charged and neutral corona micelle dispersions are observed to have corona charge dependent lipase binding and catalytic degradation by an interfacial activation pathway. P.cepacia lipase from a commercial source was recognized to contain six isoforms that may be divided into two activity categories from the observed corona charge selective catalytic micelle degradations. Both of the P.cepacia lipase types catalyze degradation of the micelles with neutral corona, but the lipase isoforms are specific for micelles that have either negatively or positively charged corona. Micelles from $\left[\mathrm{HO}-\mathrm{PCL}_{51}-b-\mathrm{PEO}_{32}-\mathrm{RCO}_{2}\right]^{-} \mathrm{Na}^{+}$that have negatively charged corona at $\mathrm{pH}$ of 7.4 selectively react with only one type of lipase isoforms (L(I)), but at $\mathrm{pH}$ of 4.0 where the carboxylate groups are protonated both types of lipase isoform components (L(I) and L(II)) react. A commercially obtained P. cepacia lipase sample was further shown to contain two types of lipase isoforms that have complementary corona charge dependent micelle degradation by partial separation. Observation of corona charge selective lipase catalyzed micelle degradation suggests that strategies that incorporate variation of corona charge could be employed in designing block copolymer micelles for therapeutic substance delivery where transport is stabilized and lipase catalyzed micelle degradation providing selective release. Expanding investigations of corona charge dependent reactions of micelles and enzymes are directed toward revealing the origin for the observed set of $P$. cepacia lipase isoforms, the enzyme structural features that result in charge dependent catalysis and whether or not these features have biological relevance. 


\section{Acknowlegdements}

Partial support of this research by NSF CHE-0957141 and funding of a JEOL JEM-1400 TEM

by the NSF CHE-0923077 are gratefully acknowledged. X.Z. acknowledges the Temple

Graduate School and the College of Science and Technology for the award of a Dissertation

Fellowship. We also thank Prof. Vincent Voelz for help with the calculations for Fig. 8.

\section{References}

[1] T.L. Andresen, S.S. Jensen, K. Jørgensen, Advanced strategies in liposomal cancer therapy: Problems and prospects of active and tumor specific drug release, Prog Lipid Res 44 (2005) 6897.

[2] Y. Tong, N. Li, H. Liu, A. Ge, M. Osawa, S. Ye, Mechanistic studies by sum-frequency generation spectroscopy: Hydrolysis of a supported phospholipid bilayer by phospholipase a2, Angew Chem Int Ed 49 (2010) 2319-23.

[3] H. Wu, L. Yu, Y. Tong, A. Ge, S. Yau, M. Osawa, et al., Enzyme-catalyzed hydrolysis of the supported phospholipid bilayers studied by atomic force microscopy, Biochim Biophys Acta 1828 (2012) 642-51.

[4] A. Arouri, O.G. Mouritsen, Phospholipase a2-susceptible liposomes of anticancer double lipid-prodrugs, Eur J Pharm Sci 45 (2012) 408-20.

[5] A. Halperin, O. Mouritsen, Role of lipid protrusions in the function of interfacial enzymes, Europhys Lett 34 (2005) 967-71.

[6] P. Hoyrup, T.H. Callisen, M.O. Jensen, A. Halperin, O.G. Mouritsen, Lipid protrusions, membrane softness, and enzymatic activity, Phys Chem Chem Phys 6 (2004) 1608-15.

[7] Y. Cajal, O.G. Berg, M.K. Jain, Origins of delays in monolayer kinetics: Phospholipase a2 paradigm $\dagger$, Biochemistry 43 (2004) 9256-64.

[8] L. Tarachiwin, J. Sakdapipanich, K. Ute, T. Kitayama, T. Bamba, E.-i. Fukusaki, et al., Structural characterization of $\alpha$-terminal group of natural rubber. 1. Decomposition of branchpoints by lipase and phosphatase treatments, Biomacromolecules 6 (2005) 1851-7.

[9] U.T. Bornscheuer, Microbial carboxyl esterases: Classification, properties and application in biocatalysis, FEMS Microbiol Rev 26 (2002) 73-81.

[10] H. Chahinian, L. Nini, E. Boitard, J.-P. Dubès, L.-C. Comeau, L. Sarda, Distinction between esterases and lipases: A kinetic study with vinyl esters and tag, Lipids 37 (2002) 653-62.

[11] H. Chahinian, J. Fantini, N. Garmy, G. Manco, L. Sarda, Non-lipolytic and lipolytic sequence-related carboxylesterases: A comparative study of the structure-function relationships of rabbit liver esterase 1 and bovine pancreatic bile-salt-activated lipase, Biochim Biophys Acta 1801 (2010) 1195-204.

[12] O.G. Berg, M.H. Gelb, M.-D. Tsai, M.K. Jain, Interfacial enzymology: The secreted phospholipase a2-paradigm, Chem Rev 101 (2001) 2613-54.

[13] L.W. Tjoelker, C. Eberhardt, J. Unger, H.L. Trong, G.A. Zimmerman, T.M. McIntyre, et al., Plasma platelet-activating factor acetylhydrolase is a secreted phospholipase a2 with a catalytic triad, J Biol Chem 270 (1995) 25481-7. 
[14] S. Spiegel, D. Foster, R. Kolesnick, Signal transduction through lipid second messengers, Curr Opin Cell Biol 8 (1996) 159-67.

[15] C. Deng, Y. Jiang, R. Cheng, F. Meng, Z. Zhong, Biodegradable polymeric micelles for targeted and controlled anticancer drug delivery: Promises, progress and prospects, Nano Today 7 (2012) 467-80.

[16] R. Langer, D.A. Tirrell, Designing materials for biology and medicine, Nature 428 (2004) 487-92.

[17] M. Elsabahy, K.L. Wooley, Design of polymeric nanoparticles for biomedical delivery applications, Chem Soc Rev 41 (2012) 2545-61.

[18] B. Surnar, M. Jayakannan, Stimuli-responsive poly(caprolactone) vesicles for dual drug delivery under the gastrointestinal tract, Biomacromolecules 14 (2013) 4377-87.

[19] T.K. Endres, M. Beck-Broichsitter, O. Samsonova, T. Renette, T.H. Kissel, Self-assembled biodegradable amphiphilic peg-pcl-lpei triblock copolymers at the borderline between micelles and nanoparticles designed for drug and gene delivery, Biomaterials 32 (2011) 7721-31.

[20] Z. Zhu, Y. Li, X. Li, R. Li, Z. Jia, B. Liu, et al., Paclitaxel-loaded poly(n-vinylpyrrolidone)b-poly( $\varepsilon$-caprolactone) nanoparticles: Preparation and antitumor activity in vivo, J Controlled Release 142 (2010) 438-46.

[21] H.M. Aliabadi, A. Mahmud, A.D. Sharifabadi, A. Lavasanifar, Micelles of methoxy poly(ethylene oxide)-b-poly( $\varepsilon$-caprolactone) as vehicles for the solubilization and controlled delivery of cyclosporine a, J Controlled Release 104 (2005) 301-11.

[22] K. Kataoka, A. Harada, Y. Nagasaki, Block copolymer micelles for drug delivery: Design, characterization and biological significance, Adv Drug Deliv Rev 47 (2001) 113-31.

[23] L.M. Ensign, C. Schneider, J.S. Suk, R. Cone, J. Hanes, Mucus penetrating nanoparticles: Biophysical tool and method of drug and gene delivery, Adv Mater 24 (2012) 3887-94. [24] V.V. Shuvaev, M.A. Ilies, E. Simone, S. Zaitsev, Y. Kim, S. Cai, et al., Endothelial targeting of antibody-decorated polymeric filomicelles, ACS Nano 5 (2011) 6991-9.

[25] X. Yue, Y. Qiao, N. Qiao, S. Guo, J. Xing, L. Deng, et al., Amphiphilic methoxy poly(ethylene glycol)-b-poly(e-caprolactone)-b-poly(2-dimethylaminoethyl methacrylate) cationic copolymer nanoparticles as a vector for gene and drug delivery, Biomacromolecules 11 (2010) 2306-12.

[26] H.Y. Cho, A. Srinivasan, J. Hong, E. Hsu, S. Liu, A. Shrivats, et al., Synthesis of biocompatible peg-based star polymers with cationic and degradable core for sirna delivery, Biomacromolecules 12 (2011) 3478-86.

[27] Z. Gan, T.F. Jim, M. Li, Z. Yuer, S. Wang, C. Wu, Enzymatic biodegradation of poly(ethylene oxide-b-e-caprolactone) diblock copolymer and its potential biomedical applications, Macromolecules 32 (1999) 590-4.

[28] M.G. Carstens, C.F. van Nostrum, R. Verrijk, L.G.J. de Leede, D.J.A. Crommelin, W.E. Hennink, A mechanistic study on the chemical and enzymatic degradation of peg-oligo( $\varepsilon$ caprolactone) micelles, J Pharm Sci 97 (2008) 506-18.

[29] Z. Jiang, Z. Zhu, C. Liu, Y. Hu, W. Wu, X. Jiang, Non-enzymatic and enzymatic degradation of poly(ethylene glycol)-b-poly( $\varepsilon$-caprolactone) diblock copolymer micelles in aqueous solution, Polymer 49 (2008) 5513-9.

[30] X. Zhu, M. Fryd, B.B. Wayland, Kinetic-mechanistic studies of lipase-polymer micelle binding and catalytic degradation: Enzyme interfacial activation, Polym Degrad Stab 98 (2013) 1173-81. 
[31] S. Li, H. Garreau, B. Pauvert, J. McGrath, A. Toniolo, M. Vert, Enzymatic degradation of block copolymers prepared from $\varepsilon$-caprolactone and poly(ethylene glycol), Biomacromolecules 3 (2002) 525-30.

[32] X.B. Zhu, M. Fryd, A.M. Valentine, B.B. Wayland, Corona charge selective micelle degradation catalyzed by p. Cepacia lipase isoforms, Chem Commun 50 (2014) 964-7. [33] X. Zhu, V.D. Sharma, M. Fryd, M.A. Ilies, B.B. Wayland, Enzyme and acid catalyzed degradation of peg45-b-pbo0,6,9-b-pcl60 micelles: Increased hydrolytic stability by engineering the hydrophilic-hydrophobic interface, Polymer 54 (2013) 2879-86.

[34] X. Zhu, M. Fryd, B.D. Tran, M.A. Ilies, B.B. Wayland, Modifying the hydrophilichydrophobic interface of peg-b-pcl to increase micelle stability: Preparation of peg-b-pbo-b-pcl triblock copolymers, micelle formation, and hydrolysis kinetics, Macromolecules 45 (2012) 6605 .

[35] C. Shen, S. Guo, C. Lu, Degradation behaviors of monomethoxy poly(ethylene glycol)-bpoly(e-caprolactone) nanoparticles in aqueous solution, Polym Adv Technol 19 (2008) 66-72. [36] N. Fairley, B. Hoang, C. Allen, Morphological control of poly(ethylene glycol)-blockpoly( $\varepsilon$-caprolactone) copolymer aggregates in aqueous solution, Biomacromolecules 9 (2008) 2283-91.

[37] G. Maglio, F. Nicodemi, C. Conte, R. Palumbo, P. Tirino, E. Panza, et al., Nanocapsules based on linear and y-shaped 3-miktoarm star-block peo-pcl copolymers as sustained delivery system for hydrophilic molecules, Biomacromolecules 12 (2011) 4221-9.

[38] R.J. Hickey, A.S. Haynes, J.M. Kikkawa, S.-J. Park, Controlling the self-assembly structure of magnetic nanoparticles and amphiphilic block-copolymers: From micelles to vesicles, J Am Chem Soc 133 (2011) 1517-25.

[39] W. Zhu, A. Nese, K. Matyjaszewski, Thermoresponsive star triblock copolymers by combination of rop and atrp: From micelles to hydrogels, J Polym Sci, Part A: Polym Chem 49 (2011) 1942-52.

[40] H.-i. Lee, W. Wu, J.K. Oh, L. Mueller, G. Sherwood, L. Peteanu, et al., Light-induced reversible formation of polymeric micelles, Angew Chem Int Ed 46 (2007) 2453-7.

[41] S.-J. Park, S.-G. Kang, M. Fryd, J.G. Saven, S.-J. Park, Highly tunable photoluminescent properties of amphiphilic conjugated block copolymers, J Am Chem Soc 132 (2010) 9931-3. [42] C.E. Hoyle, C.N. Bowman, Thiol-ene click chemistry, Angew Chem Int Ed 49 (2010) 1540-73.

[43] K.L. Killops, L.M. Campos, C.J. Hawker, Robust, efficient, and orthogonal synthesis of dendrimers via thiol-ene "click" chemistry, J Am Chem Soc 130 (2008) 5062-4.

[44] A.K. Tucker-Schwartz, R.A. Farrell, R.L. Garrell, Thiol-ene click reaction as a general route to functional trialkoxysilanes for surface coating applications, J Am Chem Soc 133 (2011) 11026-9.

[45] R. Yang, F. Meng, S. Ma, F. Huang, H. Liu, Z. Zhong, Galactose-decorated cross-linked biodegradable poly(ethylene glycol)-b-poly( $\varepsilon$-caprolactone) block copolymer micelles for enhanced hepatoma-targeting delivery of paclitaxel, Biomacromolecules 12 (2011) 3047-55. [46] S. Cammas, Y. Nagasaki, K. Kataoka, Heterobifunctional poly(ethylene oxide): Synthesis of .Alpha.-methoxy-.Omega.-amino and .Alpha.-hydroxy-.Omega.-amino peos with the same molecular weights, Bioconjugate Chem 6 (1995) 226-30.

[47] S. Schubert, J.J.T. Delaney, U.S. Schubert, Nanoprecipitation and nanoformulation of polymers: From history to powerful possibilities beyond poly(lactic acid), Soft Matter 7 (2011) $1581-8$. 
[48] Y. Hu, L. Zhang, Y. Cao, H. Ge, X. Jiang, C. Yang, Degradation behavior of poly(عcaprolactone)-b-poly(ethylene glycol)-b-poly( $\varepsilon$-caprolactone) micelles in aqueous solution, Biomacromolecules 5 (2004) 1756-62.

[49] C. Giacomelli, R. Borsali, Morphology of poly(ethylene oxide)-block-polycaprolatone block copolymer micelles controlled via the preparation method, Macromol Symp 245-246 (2006) 147-53.

[50] V. Lassalle, M.L. Ferreira, Pla nano- and microparticles for drug delivery: An overview of the methods of preparation, Macromol Biosci 7 (2007) 767-83.

[51] Y. Takano, K.N. Houk, Conformational preferences in the transition states and tetrahedral intermediates of transacylations. Relationships to enzyme-bound conformations of phosphonate inhibitors of lipases and esterases, J Phys Chem A 108 (2004) 11740-51.

[52] O. Torre, I. Alfonso, V. Gotor, Lipase catalysed michael addition of secondary amines to acrylonitrile, Chem Commun (2004) 1724-5.

[53] A. Kawamura, Y. Yoshioka, A. Harada, K. Kono, Acceleration of enzymatic reaction of trypsin through the formation of water-soluble complexes with poly(ethylene glycol)-blockpoly $(\alpha, \beta$-aspartic acid), Biomacromolecules 6 (2005) 627-31.

[54] L. Hemsath, R. Dvorsky, D. Fiegen, M.-F. Carlier, M.R. Ahmadian, An electrostatic steering mechanism of cdc42 recognition by wiskott-aldrich syndrome proteins, Mol Cell 20 (2005) 313-24.

[55] J.D. Schrag, Y. Li, M. Cygler, D. Lang, T. Burgdorf, H.-J. Hecht, et al., The open conformation of a pseudomonas lipase, Structure 5 (1997) 187-202.

[56] J.F. Shaw, C.H. Chang, Y.J. Wang, Characterization of 3 distinct forms of lipolytic enzyme in a commercial candida lipase preparation, Biotechnology Letters 11 (1989) 779-84. [57] G.L. Winsor, D.K.W. Lam, L. Fleming, R. Lo, M.D. Whiteside, N.Y. Yu, et al., Pseudomonas genome database: Improved comparative analysis and population genomics capability for pseudomonas genomes, Nucleic Acids Research 39 (2011) D596-D600. [58] G.L. Winsor, B. Khaira, T. Van Rossum, R. Lo, M.D. Whiteside, F.S.L. Brinkman, The burkholderia genome database: Facilitating flexible queries and comparative analyses, Bioinformatics 24 (2008) 2803-4.

[59] K.K. Kim, H.K. Song, D.H. Shin, K.Y. Hwang, S.W. Suh, The crystal structure of a triacylglycerol lipase from pseudomonas cepacia reveals a highly open conformation in the absence of a bound inhibitor, Structure 5 (1997) 173-85.

[60] T.N. Petersen, S. Brunak, G. von Heijne, H. Nielsen, Signalp 4.0: Discriminating signal peptides from transmembrane regions, Nature Methods 8 (2011) 785-6. 
Graphical Abstract

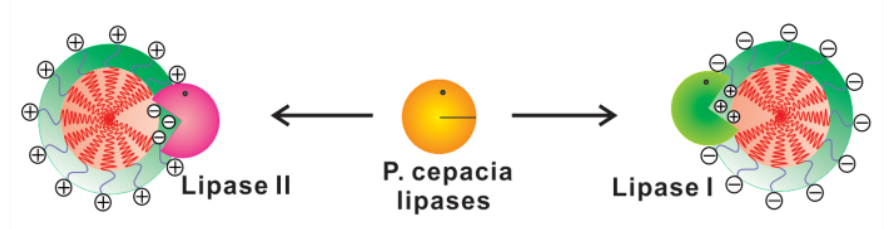

